\title{
Calf blood flow and oxygen carriage after reversal of polycythaemia secondary to hypoxic lung disease
}

\author{
PJW WALLIS, MCP APPS, AC NEWLAND, DW EMPEY \\ From the Department of Thoracic Medicine, London Hospital, London
}

ABSTRACT Reduction of packed cell volume has been recommended as a therapeutic procedure i patients with polycythaemia secondary to hypoxic lung disease. We have investigated the effects of this policy on blood flow and oxygen carriage to the calf in 12 such patients. Packed cell volume was decreased from 0.61 to 0.51 (mean) by isovolaemic haemodilution on a cell separator, wit H $^{\circ}$ significant reductions in blood viscosity at high and low shear rates. Resting calf blood flow was unchanged but peak flow during reactive hyperaemia increased by $17 \%$ and $21 \%$ one and seven days after the procedure. Oxygen carriage to the calf at rest was initially unchanged but had fallem by $20 \%$ at seven days. During reactive hyperaemia oxygen carriage was not impaired by the reduc tion in packed cell volume since the rise in blood flow offset any reduction in arterial oxygen content. This study has shown that when blood flow is stressed during reactive hyperaemia oxygege carriage is not compromised by a therapeutic reduction in packed cell volume.

Although an appreciable proportion of patients with hypoxic lung disease develop secondary polycythaemia this response may not be advantageous. An increase in packed cell volume improves the oxygen carrying capacity of the blood but is also responsible for an exponential rise in blood viscosity. ${ }^{1}$ Oxygen carriage to the tissues will be beneficial only if the increased arterial oxygen content is not offset by a reduction in blood flow due to the greater viscosity of polycythaemic blood. Experimental work has shown that polycythaemia decreases tissue blood flow and impairs tissue oxygenation, ${ }^{23}$ indicating that an optimum packed cell volume may exist for oxygen carriage. $^{4}$

Patients with polycythaemia secondary to hypoxic lung disease derive useful increases in exercise tolerance after reduction of packed cell volume to approximately 0.50 by either venesection, ${ }^{5}$ Dextran 40 exchange transfusion, ${ }^{6}$ or more recently erythrapheresis (isovolaemic haemodilution on a cell separator $)^{7}$-a response not attributable to a placebo effect. $^{8}$ The mechanisms underlying such improvement are unclear, but may include greater mental alertness due to increased cerebral blood flow ${ }^{9}$ and/or improvement in pulmonary haemodynamics. ${ }^{111}$ The effects of reduction in packed cell

Address for reprint requests: Dr DW Empey, Department of Thoracic Medicine, London Hospital, London E1 1BB.

Accepted 17 September 1985 volume on skeletal muscle blood flow and oxygen cag riage are unknown but may also be relevant to the improvement of performance indices. We have mea sured calf blood flow at rest and during reactize hyperaemia in a group of patients with hypoxic lung disease before and after reversal of polycythaemia.

\section{Methods}

Twelve patients with hypoxic lung disease and seéondary polycythaemia were studied (tables 1 and 2. All were free from oedema and were not suffering from pulmonary infection of from an acufe exacerbation of their disease. Two patients were light smokers (five cigarettes daily); the remainder wefe non-smokers. Calf blood flow was measured venous occlusion plethysmography, a Whitney mex cury in rubber strain gauge being used. ${ }^{14}$ Flows wefe measured seven days and one day before and one dăy and seven days after reduction of packed cell volume All measurements were made with the patient lying semisupine after lying for 60 minutes with the raised to $45^{\circ}$ to the horizontal. Room temperatuge was held constant $\left( \pm 0.5^{\circ} \mathrm{C}\right)$ during the course of the study. A light breakfast, without tea or coffee, was allowed at 0700-0800 hours and flows recorde日 between 1000 and 1200 hours. Methylxanthine prep 8 rations were discontinued 24 hours before stude; diuretics and inhaled $\beta_{2}$ agonists were withheld on the morning of the investigation until after the blood flow 
Table 1 Anthropometric and lung function data (percentages of predicted normal values ${ }^{12}$ in parentheses)

\begin{tabular}{|c|c|c|c|c|c|c|c|c|c|}
\hline $\begin{array}{l}\text { Patient } \\
\text { No }\end{array}$ & $\operatorname{Age}(y)$ & Sex & $\begin{array}{l}\text { Weight } \\
\text { (kg) }\end{array}$ & $\begin{array}{l}\text { Height } \\
(\mathrm{m})\end{array}$ & Diagnosis & $F E V_{1}(l)$ & $F V C(l)$ & $\begin{array}{l}\mathrm{PaCO}_{2} \\
(\mathrm{kPa})\end{array}$ & $\begin{array}{l}\mathrm{PaO}_{2} \\
(\mathrm{kPa})\end{array}$ \\
\hline $\begin{array}{r}1 \\
2 \\
3 \\
4 \\
5 \\
6 \\
7 \\
8 \\
9 \\
10 \\
11 \\
12\end{array}$ & $\begin{array}{l}67 \\
59 \\
54 \\
59 \\
64 \\
56 \\
65 \\
66 \\
63 \\
68 \\
56 \\
66\end{array}$ & $\begin{array}{l}\mathbf{M} \\
\mathbf{F} \\
\mathbf{F} \\
\mathbf{F} \\
\mathbf{M} \\
\mathbf{M} \\
\mathbf{M} \\
\mathbf{M} \\
\mathbf{M} \\
\mathbf{M} \\
\mathbf{M} \\
\mathbf{M}\end{array}$ & $\begin{array}{l}84 \\
52 \\
41 \\
74 \\
93 \\
95 \\
83 \\
83 \\
54 \\
72 \\
75 \\
65\end{array}$ & $\begin{array}{l}1.64 \\
1.55 \\
1.55 \\
1.59 \\
1.74 \\
1.61 \\
1.66 \\
1.65 \\
1.67 \\
1.64 \\
1.75 \\
1.78\end{array}$ & $\begin{array}{l}\text { A } \\
\text { CAO } \\
\text { CAO } \\
\text { CAO } \\
\text { CAO } \\
\text { CAO } \\
\text { CAO + L } \\
\text { CAO } \\
\text { CAO } \\
\text { CAO } \\
\text { CAO } \\
\text { CAO }\end{array}$ & $\begin{array}{l}0.9(38) \\
0.5(26) \\
0.6(28) \\
1.0(49) \\
0.4(14) \\
0.4(15) \\
0.2(8) \\
0.4(16) \\
0.7(26) \\
0.5(20) \\
0.3(10) \\
0.7(23)\end{array}$ & $\begin{array}{ll}1.4 & (40) \\
1.2 & (51) \\
1.6 & (64) \\
2.7 & (108) \\
1.6 & (40) \\
1.3 & (37) \\
0.8 & (22) \\
0.8 & (23) \\
1.8 & (49) \\
1.7 & (49) \\
1.2 & (28) \\
2.0 & (48)\end{array}$ & $\begin{array}{r}5.1 \\
8.3 \\
5.6 \\
5.9 \\
8.2 \\
6.5 \\
7.2 \\
6.8 \\
7.1 \\
6.3 \\
10.1 \\
7.1\end{array}$ & $\begin{array}{l}7.4 \\
7.1 \\
4.9 \\
7.5 \\
6.4 \\
7.6 \\
7.6 \\
8.3 \\
7.7 \\
7.5 \\
4.8 \\
6.3\end{array}$ \\
\hline
\end{tabular}

A-asbestosis; CAO-chronic airflow obstruction; L-lobectomy for bronchial carcinoma; FVC-forced vital capacity; Paco ${ }_{2}$, $\mathrm{PaO}_{2}$ - carbon dioxide and oxygen tensions.

Conversion: SI to traditional units-Blood gas tensions: $1 \mathrm{kPa}=7.5 \mathrm{~mm} \mathrm{Hg}$.

measurements. Other treatment, including the usual diuretic dose, was continued unaltered during the study. No oxygen was administered during the study period. Smokers were asked to refrain from smoking 24 hours before the investigation and had a carboxyhaemoglobin concentration of less than $1 \%$.

After resting calf blood flow had been recorded peak calf flow during reactive hyperaemia was measured after four minutes of arterial occlusion at the thigh. All measurements were made with the foot isolated from the circulation by an ankle pressure cuff inflated to $250 \mathrm{~mm} \mathrm{Hg}$.

Arterial blood pressure was measured with a sphygmomanometer after the patients had lain semisupine for 60 minutes. Venous blood was obtained without stasis and arterial blood sampled by radial artery puncture at the end of the investigation. Haemoglobin concentration ( $\mathrm{Hb}$ ) was measured in a Coulter Counter Model S plus IV. Packed cell volume was measured by centrifuging a capillary tube blood sample for 10 minutes at $1200 \mathrm{~g}$ and correcting for trapped plasma by labelling albumin with iodine 125 .
Blood viscosity was determined in a Wells Brookfield cone and plate viscometer; carboxyhaemoglobin was measured spectrophotometrically; ${ }^{15}$ and blood gas tensions were measured with a Radiometer ABLI analyser. Haemoglobin oxygen saturation $\left(\mathrm{SaO}_{2}\right)$ was calculated from arterial oxygen tension $\left(\mathrm{PaO}_{2}\right)$ by reference to the oxygen-haemoglobin dissociation curve $^{16}$ with corrections for shifts in the standard curve due to $\mathrm{pH}$, temperature, and base excess differences. ${ }^{17}$ Reduction of packed cell volume in similar patients has been shown not to affect the position or shape of the oxygen-haemoglobin dissociation curve (JA Wedzicha, unpublished observations). Arterial oxygen content $\left(\mathrm{CaO}_{2}, \mathrm{ml} / \mathrm{dl}\right)$ was calculated from the formula:

$$
\left(1.39 \times \mathrm{Hb} \times \mathrm{SaO}_{2}\right)+\left(0.003 \times \mathrm{PaO}_{2}\right),
$$

where $\mathrm{PaO}_{2}$ is expressed in $\mathrm{mm} \mathrm{Hg}$.

Oxygen carriage to the calf was obtained from the product of calf blood flow and arterial oxygen content.

Packed cell volume was lowered to about 0.50 by erythrapheresis using a Haemonetics V50 pheresis

Table 2 Haematological data before and after erythrapheresis (percentages of predicted normal values ${ }^{13}$ in parentheses)

\begin{tabular}{|c|c|c|c|c|c|c|c|c|c|c|c|}
\hline \multirow{3}{*}{$\begin{array}{l}\text { Patient } \\
\text { No }\end{array}$} & \multicolumn{2}{|c|}{ Haemoglobin (g/dl) } & \multicolumn{2}{|c|}{ Packed cell volume } & \multicolumn{4}{|c|}{ Blood viscosity ( $\mathrm{mPa}$ s) } & \multirow{3}{*}{$\begin{array}{l}\text { Red cell mass } \\
\text { (ml/kg) } \\
\text { Before }\end{array}$} & \multirow{3}{*}{$\begin{array}{l}\text { Blood volume } \\
\text { ( } \mathrm{ml} / \mathrm{kg}) \\
\text { Before }\end{array}$} & \multirow{3}{*}{$\begin{array}{l}\text { Packed red } \\
\text { cells } \\
\text { removed }\end{array}$} \\
\hline & \multirow[t]{2}{*}{ Before } & \multirow[t]{2}{*}{ After } & \multirow[t]{2}{*}{ Before } & \multirow[t]{2}{*}{ After } & \multirow{2}{*}{$\frac{23 / s}{\text { Before }}$} & \multirow{2}{*}{ After } & \multicolumn{2}{|l|}{$230 / s$} & & & \\
\hline & & & & & & & Before & After & & & \\
\hline $\begin{array}{l}1 \\
2 \\
3 \\
4 \\
5 \\
6 \\
7 \\
8 \\
9 \\
10 \\
11 \\
12 \\
\text { Mean } \\
\text { SEM }\end{array}$ & $\begin{array}{r}17.0 \\
16.0 \\
18.9 \\
18.4 \\
20.6 \\
18.2 \\
18.3 \\
17.4 \\
17.8 \\
20.2 \\
18.9 \\
21.1 \\
18.6 \\
0.4\end{array}$ & $\begin{array}{l}15.4 \\
14.6 \\
14.2 \\
15.4 \\
16.1 \\
15.4 \\
15.6 \\
15.8 \\
16.3 \\
16.4 \\
16.0 \\
16.4 \\
15.6 \\
0.2\end{array}$ & $\begin{array}{l}0.56 \\
0.58 \\
0.61 \\
0.55 \\
0.72 \\
0.59 \\
0.59 \\
0.55 \\
0.63 \\
0.61 \\
0.61 \\
0.67 \\
0.61 \\
0.01\end{array}$ & $\begin{array}{l}0.50 \\
0.48 \\
0.45 \\
0.48 \\
0.59 \\
0.49 \\
0.49 \\
0.50 \\
0.53 \\
0.49 \\
0.52 \\
0.54 \\
0.57 \\
0.01\end{array}$ & $\begin{array}{r}10.5 \\
14.2 \\
13.2 \\
10.3 \\
18.9 \\
9.2 \\
9.2 \\
10.0 \\
12.0 \\
13.0 \\
9.5 \\
19.5 \\
12.5 \\
1.0\end{array}$ & $\begin{array}{r}8.5 \\
8.3 \\
6.8 \\
5.9 \\
9.9 \\
5.7 \\
6.0 \\
6.3 \\
7.0 \\
7.4 \\
5.8 \\
10.5 \\
7.3 \\
0.5\end{array}$ & $\begin{array}{r}5.9 \\
7.7 \\
7.6 \\
6.2 \\
9.9 \\
5.6 \\
5.6 \\
5.9 \\
7.7 \\
7.2 \\
5.9 \\
10.0 \\
7.1 \\
0.5\end{array}$ & $\begin{array}{l}4.6 \\
4.8 \\
4.3 \\
3.8 \\
5.1 \\
3.9 \\
3.6 \\
4.2 \\
4.8 \\
4.7 \\
3.6 \\
3.9 \\
4.3 \\
0.2\end{array}$ & $\begin{array}{l}32(130) \\
57(242) \\
41(147) \\
- \\
- \\
28(118) \\
-30(115) \\
68(211) \\
\overline{49}(172) \\
61(197) \\
44(163) \\
4(13)\end{array}$ & $\begin{array}{rr}64 & (111) \\
106 & (173) \\
79 & (110) \\
- & \\
-55 & (99) \\
- & \\
56 & (94) \\
121 & (161) \\
- & \\
89 & (133) \\
94 & (130) \\
81 & (125) \\
7 & (8)\end{array}$ & $\begin{array}{r}7 \\
10 \\
12 \\
7 \\
17 \\
8 \\
7 \\
6 \\
13 \\
15 \\
11 \\
21 \\
11 \\
1\end{array}$ \\
\hline
\end{tabular}

Conversion: SI to traditional units-Viscosity: $1 \mathrm{mPa} \mathrm{s}=1 \mathrm{cps}$. 


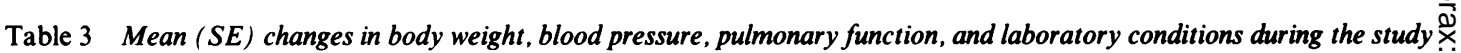

\begin{tabular}{|c|c|c|c|c|c|c|}
\hline & Before & $\begin{array}{l}\text { After } \\
(\text { day }+1) n=12\end{array}$ & $p$ & $\begin{array}{l}\text { After } \\
(\text { day }+7) n=9\end{array}$ & $p$ & $\frac{\overline{\bar{N}}}{\stackrel{+}{0}}$ \\
\hline $\begin{array}{l}\text { Body weight }(\mathrm{kg}) \\
\text { Mean blood pressure }(\mathrm{mm} \mathrm{Hg}) \\
\mathrm{FEV}_{1}(\mathrm{l}) \\
\mathrm{FVC}(\mathrm{l}) \\
\mathrm{PaCO}_{2}(\mathrm{kPa}) \\
\mathrm{PaO}_{2}(\mathrm{kPa}) \\
\mathrm{Room} \text { temperature }\left({ }^{\circ} \mathrm{C}\right) \\
\text { Skin temperature }\left({ }^{\circ} \mathrm{C}\right)\end{array}$ & $\begin{array}{l}73(5) \\
88(4) \\
0.6(0.1) \\
1.5(0.2) \\
7.0(0.4) \\
6.9(0.3) \\
21.6(0.2) \\
30.9(0.3)\end{array}$ & $\begin{array}{c}-0.5(0.2) \\
-4(3) \\
0(0.1) \\
0(0.1) \\
+0.1(0.1) \\
0(0.2) \\
-0.1(0.2) \\
+0.3(0.4)\end{array}$ & $\begin{array}{l}<0.05 \\
\text { NS } \\
\text { NS } \\
\text { NS } \\
\text { NS } \\
\text { NS } \\
\text { NS } \\
\text { NS }\end{array}$ & $\begin{array}{l}-0.3(0.4) \\
-8(4) \\
0 \quad(0.1) \\
0(0.1) \\
+0.2(0.3) \\
+0.2(0.2) \\
-0.1(0.2) \\
+0.1(0.4)\end{array}$ & $\begin{array}{l}\text { NS } \\
\text { NS } \\
\text { NS } \\
\text { NS } \\
\text { NS } \\
\text { NS } \\
\text { NS } \\
\text { NS }\end{array}$ & 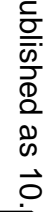 \\
\hline
\end{tabular}

system, packed red cells (packed cell volume 0.80 ) being replaced with an equal volume of human plasma protein fraction BP. Red cell mass was measured by injection of ${ }^{51} \mathrm{Cr}$ labelled autologous red blood cells. $\mathrm{FEV}_{1}$ and forced vital capacity (FVC) were measured with a Vitalograph spirometer.

Informed written consent was obtained from each patient and the study was approved by the London Hospital ethics committee. Student's $t$ test (paired, two tailed) was used to compare any differences between measurements made before and after erythrapheresis. Values are expressed as means with standard errors in parentheses. A p value of less than 0.05 was considered significant.

\section{Results}

Three patients were assessed only twice, before and one day after erythrapheresis, for the following reasons: diuretic dosage was inadvertently increased during the last week of the study in patient 1; patient 3 declined further investigation; and an infective exacerbation supervened during the final week of the study in patient 11. At other times during the study the patients remained clinically stable with no change in pulmonary function, arterial blood gas tensions $\overrightarrow{q r}$ systemic blood pressure. Laboratory conditions alsio remained constant, with no appreciable alteration room or calf skin temperature. A transient fall body weight was observed one day after the reduction in packed cell volume (table 3).

Blood viscosity was raised in every patient befoze erythrapheresis and the reduction in mean packed ceft volume from $0.61(0.01)$ to $0.51(0.01)$ lowered blog viscosity by $42 \%$ at shear rate $23 / \mathrm{s}$ and $39 \%$ at shear rate $230 / \mathrm{s}(-5.2(0.6) \mathrm{mPas}$ and $-2.8(0.4) \mathrm{mPas}$ respectively; $p<0.001$ ) (table 2 ).

CALF BLOOD FLOW (table 4)

Resting calf blood flow was unchanged one and seve days after erythrapheresis $(-0.01(0.19)$ and $-0 . \overrightarrow{0}$

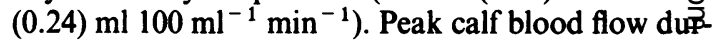

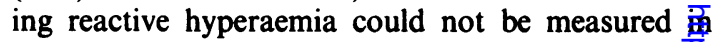
patient 3 owing to discomfort from the thigh cuff. the remaining subjects peak calf flow increased $17 \%$ one day after erythrapheresis and $21 \%$ seven days after $(+2.37(0.56), \mathrm{p}<0.01$; and $+2.99(1.0 .0)$ $\left.\mathrm{ml} 100 \mathrm{ml}^{-1} \min ^{-1}, \mathrm{p}<0.02\right)$. There was, howevef,

Table 4 Calf blood flow before and one and seven days after reduction in packed cell volume

\begin{tabular}{|c|c|c|c|c|c|c|}
\hline \multirow[t]{3}{*}{ Patient No } & \multicolumn{3}{|c|}{ Resting flow ( $\left.\mathrm{ml} 100 \mathrm{ml}^{-1} \mathrm{~min}^{-1}\right)$} & \multicolumn{3}{|c|}{ Peak hyperaemic flow $\left(100 \mathrm{ml}^{-1} \mathrm{~min}^{-1}\right)$} \\
\hline & \multirow[t]{2}{*}{ Before } & \multicolumn{2}{|l|}{ After } & \multirow[t]{2}{*}{ Before } & \multicolumn{2}{|c|}{ After } \\
\hline & & $D a y+I$ & Day + 7 & & Day + 1 & Day $+\bar{\chi}$ \\
\hline $\begin{array}{r}1 \\
2 \\
3 \\
4 \\
5 \\
6 \\
7 \\
8 \\
9 \\
10 \\
11 \\
12\end{array}$ & $\begin{array}{l}2.4 \\
3.5 \\
1.6 \\
1.9 \\
1.0 \\
4.0 \\
1.3 \\
2.5 \\
2.5 \\
1.8 \\
2.0 \\
1.3\end{array}$ & $\begin{array}{c}0 \\
-1.4 \\
-1.1 \\
0 \\
+0.2 \\
+0.6 \\
+0.3 \\
+1.0 \\
-0.3 \\
+0.3 \\
+0.4 \\
-0.1\end{array}$ & $\begin{array}{l}- \\
-1.1 \\
- \\
+0.3 \\
+0.2 \\
+0.9 \\
+0.7 \\
-0.4 \\
-1.1 \\
+0.2 \\
-0.5\end{array}$ & $\begin{array}{l}7.7 \\
13.6 \\
14.6 \\
15.8 \\
15.7 \\
11.2 \\
14.3 \\
18.1 \\
19.3 \\
14.6 \\
10.4\end{array}$ & $\begin{array}{l}+1.9 \\
-1.6 \\
+1.2 \\
+4.8 \\
+4.9 \\
+2.1 \\
+2.3 \\
+1.2 \\
+2.6 \\
+4.2 \\
+2.5\end{array}$ & $\begin{array}{l}-3.4 \\
+3 \\
+4.9 \\
+3.5 \\
+1.1 \\
+3.4 \\
+6.8 \\
-3.6 \\
+5.3 \\
+2.1\end{array}$ \\
\hline $\begin{array}{l}\text { Mean } \\
\text { SEM } \\
\text { p value }\end{array}$ & $\begin{array}{l}2.15 \\
0.26 \\
-\end{array}$ & $\begin{array}{l}-0.01 \\
0.19 \\
\mathrm{NS}\end{array}$ & $\begin{array}{l}-0.09 \\
0.24 \\
\mathrm{NS}\end{array}$ & $\begin{array}{l}14.12 \\
1.01 \\
-\end{array}$ & $\begin{array}{r}+2.37 \\
0.56 \\
<0.01\end{array}$ & $\begin{array}{r}+2.99 \\
1.00 \\
<0.02\end{array}$ \\
\hline
\end{tabular}


Table 5 Oxygen carriage to the calf before and one and seven days after reduction in packed cell volume

\begin{tabular}{|c|c|c|c|c|c|c|}
\hline \multirow[t]{3}{*}{ Patient No } & \multicolumn{3}{|c|}{$\begin{array}{l}\text { Resting oxygen carriage } \\
\left(\mathrm{ml} 100 \mathrm{ml}^{-1} \mathrm{~min}^{-1}\right)\end{array}$} & \multicolumn{3}{|c|}{$\begin{array}{l}\text { Peak hyperaemic oxygen carriage } \\
\left(\mathrm{ml} 100 \mathrm{ml}^{-1} \min ^{-1}\right)\end{array}$} \\
\hline & \multirow[t]{2}{*}{ Before } & \multicolumn{2}{|l|}{ After } & \multirow[t]{2}{*}{ Before } & \multicolumn{2}{|l|}{ After } \\
\hline & & $D a y+1$ & Day +7 & & $D a y+1$ & Day +7 \\
\hline $\begin{array}{r}1 \\
2 \\
3 \\
4 \\
5 \\
6 \\
7 \\
8 \\
9 \\
10 \\
11 \\
12\end{array}$ & $\begin{array}{l}0.49 \\
0.66 \\
0.31 \\
0.43 \\
0.23 \\
0.91 \\
0.29 \\
0.55 \\
0.55 \\
0.45 \\
0.32 \\
0.31\end{array}$ & $\begin{array}{c}-0.04 \\
-0.31 \\
-0.24 \\
-0.10 \\
-0.05 \\
-0.04 \\
+0.03 \\
+0.16 \\
-0.10 \\
-0.02 \\
0 \\
-0.08\end{array}$ & $\begin{array}{l}-\overline{0.21} \\
-\overline{0.04} \\
-0.08 \\
-0.03 \\
+0.10 \\
-0.12 \\
-0.26 \\
-0.04 \\
-\overline{0.15}\end{array}$ & $\begin{array}{l}1.59 \\
2.58 \\
3.28 \\
3.62 \\
3.59 \\
2.46 \\
3.13 \\
3.95 \\
4.79 \\
2.34 \\
2.49\end{array}$ & $\begin{array}{l}+0.21 \\
-0.60 \\
-0.58 \\
-0.14 \\
+0.32 \\
+0.19 \\
+0.22 \\
-0.03 \\
-0.34 \\
+0.19 \\
-0.02\end{array}$ & $\begin{array}{l}+\overline{0.60} \\
+\overline{0.21} \\
+0.11 \\
+0.58 \\
+0.38 \\
+1.14 \\
-0.97 \\
+0.22 \\
+\overline{0} \\
+0.07\end{array}$ \\
\hline $\begin{array}{l}\text { Mean } \\
\text { SEM } \\
\text { p value }\end{array}$ & $\begin{array}{l}0.458 \\
0.056 \\
-\end{array}$ & $\begin{array}{l}-0.066 \\
0.035 \\
\text { NS }\end{array}$ & $\begin{array}{c}-0.092 \\
0.036 \\
<0.05\end{array}$ & $\begin{array}{l}3.075 \\
0.270 \\
-\end{array}$ & $\begin{array}{l}-0.053 \\
0.099 \\
\text { NS }\end{array}$ & $\begin{array}{l}+0.131 \\
0.205 \\
\text { NS }\end{array}$ \\
\hline
\end{tabular}

no correlation between the change in peak hyperaemic flow and the reduction in blood viscosity $(23 / \mathrm{s}$ $\mathrm{r}=-0.018,230 / \mathrm{s} \mathrm{r}=-0.092 ; \mathrm{n}=11$ ) or the fall in arterial oxygen content $(r=-0.458 ; n=11)$.

OXYGEN CARRIAGE TO THE CALF (table 5)

Arterial oxygen content decreased by $17 \%$ one day and $15 \%$ seven days after erythrapheresis $(-3.61$ $(0.55)$ and $-3.17(0.61) \mathrm{ml} / \mathrm{dl} ; \mathrm{p}<0.001)$. Resting oxygen carriage to the calf was unchanged one day after reduction in packed cell volume $(-0.066(0.035)$ $\mathrm{ml} 100 \mathrm{ml}^{-1} \mathrm{~min}^{-1}$ ) but decreased by $20 \%$ seven days after the procedure $\left(-0.092(0.036) \mathrm{ml} 100 \mathrm{ml}^{-1}\right.$ $\min ^{-1} ; \mathrm{p}<0.05$ ). Because there was an increase in peak calf blood flow during reactive hyperaemia, oxygen carriage to the calf during peak flow was maintained one day and seven days after erythrapheresis $\left(-0.053(0.099)\right.$ and $-0.131(0.205) \mathrm{ml}_{100 \mathrm{ml}^{-1}}$ $\left.\min ^{-1}\right)$. No ischaemic symptoms occurred in any of the patients at rest or during exercise after the procedure.

\section{Discussion}

This study shows that reducing blood viscosity by lowering packed cell volume does not impair oxygen carriage to the calf during reactive hyperaemia. At rest, however, a reduction in oxygen carriage is observed one week after the procedure. These findings conflict with the results of acute studies in animals, where reducing blood viscosity by reversing polycythaemia produces an improvement in blood flow that more than compensates for the reduction in arterial oxygen content. ${ }^{23}$ These animal studies, however, are unlikely to represent fully the chronic condition that exists in patients with polycythaemia secondary to hypoxic lung disease, in whom compen- satory mechanisms operate to maintain cardiac output, ${ }^{18}$ and therefore oxygen transport, within normal limits.

Our findings are also at variance with those of Milligan et al, ${ }^{19}$ who found a reduction in haemoglobin transport to the calf at rest and during reactive hyperaemia after venesection in patients with primary polycythaemia and polycythaemia secondary to cyanotic heart disease. This discrepancy might result from the use of venesection by Milligan et al, a technique that produces an immediate fall in both blood volume and cardiac output. ${ }^{20}$ By replacing packed red cells with an equal volume of plasma protein fraction, erythrapheresis produces a more gradual reduction in blood volume, thus avoiding any sudden fall in cardiac output immediately after the procedure. ${ }^{21}$

Of interest is our finding that, despite the considerable reduction in blood viscosity at both high and low shear rates, no increase in resting blood flow to the calf occurred and only a relatively small increase in peak calf blood flow was observed during reactive hyperaemia. Packed cell volume is certainly the most important determinant of blood viscosity ${ }^{22}$ but its effect in vivo is not as marked as in vitro ${ }^{23}{ }^{24}$ owing to the reduced viscosity of blood in small vessels. ${ }^{25}$ This may account for the present observations since measurements of blood viscosity were made in vitro.

Our record of calf blood flow using the Whitney strain gauge plethysmograph of course provides no information about the nature of blood flow within the microcirculation of the calf. After reduction of packed cell volume the improved rheological properties of the blood might enhance skeletal muscle microperfusion by increasing capillary flow and by recruitment of previously non-perfused capillaries as well as by reducing both plasma skimming and arteriovenous shunting of red cells. This could increase 
oxygen availability within calf muscle even though the amount of oxygen carried to the calf does not rise. Alternatively, by increasing blood flow to the calf while maintaining oxygen carriage, reduction of packed cell volume might facilitate the removal of lactic acid, thereby enabling exercise tolerance to increase.

Although we and others have recommended that blood viscosity should be decreased by reversing polycythaemia in patients with hypoxic lung disease, ${ }^{7826}$ it is important to ensure that any reduction in the oxygen carrying capacity of the blood does not impair tissue oxygenation. In this study the fall in oxygen carriage to the calf at rest, one week after erythrapheresis, did not prove deleterious. Furthermore, we have shown that when blood flow to the calf is stressed during reactive hyperaemia, as it is during exercise, oxygen carriage is not compromised by a reduction in packed cell volume to about 0.50 .

\section{References}

1 Dormandy JA. Clinical significance of blood viscosity. Ann $R$ Coll Surg Engl 1970;47:211-28.

2 Murray JF, Gold P, Johnson BL. Systemic oxygen transport in induced normovolemic anemia and polycythemia. Am J Physiol 1962;203:720-4.

3 Replogle RJ, Merrill EW. Experimental polycythemia and hemodilution: physiologic and rheologic effects. $J$ Thorac Cardiovasc Surg 1970;60:582-8.

4 Crowell JW, Smith ED. Determinant of the optimal hematocrit. J Appl Physiol 1967;22:501-4.

5 Chetty KG, Brown SE, Light RW. Improved exercise tolerance of the polycythemic lung patient following phlebotomy. Am J Med 1983;74:415-20.

6 Harrison BDW, Gregory RJ, Clark TJH, Scott GW. Exchange transfusion with Dextran 40 in polycythaemia secondary to hypoxic lung disease. $\mathrm{Br} \mathrm{Med} J$ 1971;iv:713-6.

7 Wedzicha JA, Rudd RM, Apps MCP, Cotter FE, Newland AC, Empey DW. Erythrapheresis in patients with polycythaemia secondary to hypoxic lung disease. $\mathrm{Br}$ Med J 1983;286:511-4.

8 Wedzicha JA, Cotter FE, Rudd RM, Apps MCP, Newland AC, Empey DW. Erythrapheresis compared with placebo apheresis in patients with polycythaemia secondary to hypoxic lung disease. Eur $J$ Respir Dis 1985;65:579-85.

9 Wade JPH, Pearson TC, Russell RWR, WetherleyMein G. Cerebral blood flow and blood viscosity in patients with polycythaemia secondary to hypoxic lung disease. Br Med J 1981;283:689-92.

10 Weiss AB, Mochos CB, Frank MJ, Levinson GE, Cannilla JE, Regan TJ. Hemodynamic effects of staged he matocrit reduction in patients with stable cor pulmonale and severely elevated hematocrit levels. $A$ in J Med 1975;58:92-3.

11 Harrison BDW, Davis J, Madgwick RG, Evans M. The effects of therapeutic disease in packed cell volume of the responses to exercise of patients with polycythaemia secondary to lung disease. Clin Sci Mol Med 1973p 45:833-47.

12 Cotes JE. Lung function: assessment and application in. medicine. 4th ed. Oxford: Blackwell Scientific Publica tions, 1979.

13 Nadler SB, Hidalgo JU, Bloch T. Prediction of bloof volume in normal human adults. Surgery 1962;51 224-32.

14 Whitney RJ. The measurement of volume changes id human limbs. J Physiol 1953;121:1-27.

15 Dacie JV, Lewis SM. Practical haematology. Edinم burgh: Churchill Livingstone, 1984.

16 Severinghaus JW. Blood gas concentrations. In: Fenn? WO, Rahn H, eds. Handbook of physiology. Vol 2 Washington DC: American Physiological Society 1968:1475-87.

17 Kellman GR, Nunn JF. Computer predicted physio $\overrightarrow{\overrightarrow{0}}$ logical tables. London: Butterworths, 1968.

18 Wade OL, Bishop JM. Cardiac output and regional blood flow. Oxford: Blackwell Scientific Publications? 1962.

19 Milligan DW, Tooke JE, Davies JA. Effect of venesec tion on calf blood flow in polycythaemia. $\mathrm{Br} \mathrm{Med} \Phi$ 1982;284:619-20.

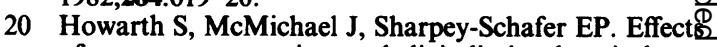
of oxygen, venesection and digitalis in chronic hear failure from disease of the lungs. Clin Sci 1967\% 6:187-96.

21 Newland AC, Wedzicha JA. Isovolaemic Haemo dilution (erythrapheresis) in polycythaemia. Apheresis. Bulletin 1984;2:24-33.

22 Begg TB, Hearns JB. Components in blood viscosityọ The relative contribution of haematocrit, plasmఖ fibrinogen and other proteins. Clin Sci 1966;31:87-93.

23 Whittaker SRF, Winton FR. The apparent viscosity o blood following in the isolated hind limb of the dog and its variation with corpuscular concentration. I Physiol 1933;78:339-69.

24 Levy MN, Share L. The influence of erythrocyte cone centration upon the pressure-flow relationships in the dog's hind limb. Circ Res 1953;1:247-55.

25 Fåhraeus $R$, Lindqvist $T$. The viscosity of the blood in narrow capillary tubes. Am J Physiol 1931;96:562-8. N

26 Harrison BDW, Stokes TC. Secondary polycythaemia: its causes, effects and treatment. $\mathrm{Br} J$ Dis Chest 1982 76:313-40. 